\title{
ENGLISH VERSION: NATURAL PEPTIDE COMPLEXES OF THYMUS AND KIDNEYS REINFORCE APOPTOSIS OF TRANSFORMED T-CELLS, BUT DO NOT AFFECT THE PROCESSES OF APOPTOSIS IN B-CELLS*
}

\author{
Shlykova O.A., Izmailova O.V., Lysanets Yu.V. \\ Ukrainian Medical Stomatological Academy, Poltava
}

One of the most important issues in modern medicine is the search for methods for regulating programmed cell death in order to develop new approaches to treatment, including cancer and leukemia. Humoral regulation of theprocesses of apoptosis with the help of cytokines, hormones, growth factors, peptides plays an important role in the mechanisms of regulation of apoptosis. The effect of natural peptide complexes of thymus and kidneys on HPB-ALL (acute T-cell leukemia) and BJAB (Berkita lymphoma) cell apoptosis processes has been studied. It has been shown that the natural peptide complexes of the thymus and the kidneys have little stimulating effect on the apoptosis of BJAB tumor $B$ cells at low concentrations, and when increasing the dose of peptides, they do not affect the processes of apoptosis; it is believed that the processes of elimination of transformed T-cells are enhanced by activating apoptosis processes in them. With the action of the natural peptide complex of thymus, this effect has a dose-dependent nature - increases with raising the dose.

Key words: apoptosis, natural peptide complexes of thymus and kidneys, transformed T- and B-cells.

Apoptosis plays a key role in the removal of adverse or potentially dangerous cells from the body, for example, the transformed cells [1]. The literary sources provide evidence that suppression of apoptosis may be one of the reasons for the increase of proliferative activity of precancerous and cancerous tumors [2].

Disrupted course of apoptotic processes may infringe the homeostasis of the lymphoproliferative system and lead to the development of leukemia and lymphoma [3]. Experimental confirmation has been made that the basis of many lymphoproliferative diseases is the process of cellular apoptosis disruption by the type of block of negative effects of activation, resulting in unrestrained cell proliferation [4].

Defects of apoptosis are at the basis of both tumor formation and the appearance of resistance of tumors to medications $[5,6]$. Therefore, one of the most important issues is the search for methods of regulating programmed cell death in order to develop new approaches to the treatment of cancer and leukemia. The inhibitory effects may be targeted at different levels of regulation: interception of the stimulus, formation of antagonism to the inductor, termination of signal transduction, blockade of cellular catalytic enzymes - participants in the cellular suicide $[7,8]$.

Humoral regulation of the processes of apoptosis with the help of cytokines, hormones, growth factors and peptides plays an important role in the mechanisms of regulation of apoptosis.

The study of the mechanisms in the influence of regulatory peptides on apoptosis processes is currently given considerable attention, as the data on the amplification or inhibition of the apoptosis processes of cells in various tissues under the influence of peptide substances are gradually accumulated $[9,10]$.

It has been shown that synthesized pro-apoptotic peptides possess the anti-tumor activity against the blood vessel tumors in mice. When penetrated into the middle of the cell, they damage the membranes of mitochondria, causing the death of endothelial tumor cells [11]. The data on the anti-carcinogenic properties in peptides isolated from the thymus have been obtained [12].

The aim of the research was to study the effects of natural peptide complexes of the thymus and kidneys on the processes of apoptosis in HPB-ALL cells (acute T-cell leukosis) and BJAB (Burkitt's lymphoma).

\section{Materials and methods}

The studies were conducted on cells of the BJAB line (Burkitt's lymphoma) and HBP-ALL cells (acute T-cell leukosis). Cells were cultured in the RPMI-1640 (Gibco $B R L)$ medium with the addition of $10 \%$ fetal bovine serum (BioMark), $10 \mathrm{mM}$ HEPES (SIGMA, USA) and $100 \mu \mathrm{g} / \mathrm{ml}$ gentamicin sulfate (GNTSLS, Ukraine). The natural peptide complex of thymus (thymalin) (Russia, St. Petersburg, ZMP) and the natural peptide complex of the kidneys (NPCK) [13] were added to a culture medium at a concentration of $0.01 \mu \mathrm{g} / \mathrm{ml}, 0.1 \mu \mathrm{g} / \mathrm{ml}, 1 \mu \mathrm{g} / \mathrm{ml}, 10$ $\mu \mathrm{g} / \mathrm{ml}$, respectively, and incubated for 24 hours at $37^{\circ} \mathrm{C}$ in a moist air with $5 \% \mathrm{CO}_{2}$.

The morphological changes in apoptosis were studied: hyperchromicity of nuclei, condensation and fragmentation of chromatin. In addition to classical MayGrünwald- Romanowsky staining [14], we also used a fluorescent "nuclear" dye Hoechst 33342 [15]. The number of cells with morphological features of apoptosis was calculated as the percentage of cells with fragmentation or condensation of chromatin per 100 lymphocytes.

The DNA from the transformed cells under consideration was isolated using the phenol-chloroform method. An intercellular DNA fragmentation analysis was performed in the form of "steps" that occurs consistently in DNA splitting by endonuclease, using an agarose gel electrophoresis with visualization of the results in ultraviolet light in the presence of bromide etidium [14]. DNA molecules of $\lambda$-phage were used as markers of molecular weight after treatment with restrictase Pst 1 . The results were photographed.

The total number of cells was counted in $1 \mathrm{ml}$ of suspension. Differentiation of living and dead cells was performed by staining the cells with acridine orange / ethidium bromide dye to estimate the percentage of cells present in the state of apoptosis [16].

The number of green (living) and orange (dead) cells was counted using a Lumam-P-8 microscope (Lomo, Russia), magnified at x360 under a fluorescence microscope in ultraviolet light and the visible part of the spectrum. The number of dead and living cells was calculated

\footnotetext{
* To cite this English version: O.A. Shlykova, O.V. Izmailova, Yu.V. Lysanets. Natural peptide complexes of thymus and kidneys reinforce apoptosis of transformed t-cells, but do not affect the processes of apoptosis in b-cells // Problemy ekologii ta medytsyny. 2018. - Vol 22, № 3-4. - P. 30-34.
} 
as the percentage of cells with an orange and green color, respectively, per 100 cells.

\section{Results and discussion}

The study of the total number of BJAB cells and their viability demonstrated that in the parent culture, the total number of cells was $3.0 \pm 0.4 \times 10^{6} / \mathrm{ml}$, the percentage of dead cells was $4.6 \pm 0.8$. The number of cells with thymalin at a minimum dose of $0.01 \mu \mathrm{g} / \mathrm{ml}$ and a dose of
$0.1 \mu \mathrm{g} / \mathrm{ml}$ slightly increased. At doses of $1 \mu \mathrm{g} / \mathrm{ml}$ and $10 \mu \mathrm{g} / \mathrm{ml}$, the total number of cells was equal to the control group. Percentage of dead cells was almost unchanged under the action of thymalin and NPCK at doses of $0.01 \mu \mathrm{g} / \mathrm{ml}, 0.1 \mu \mathrm{g} / \mathrm{ml}$ in comparison with control cells. With an increase in the dose of peptides, it was equal to the control group (Table 1).

Total amount and viability of BJAB cells under the action of thymalin and NPCK

\begin{tabular}{|c|c|c|c|c|c|c|c|c|c|}
\hline \multirow{2}{*}{ Parameter } & \multirow{2}{*}{ Control } & \multicolumn{4}{|c|}{ Thymalin, $\mu \mathrm{g} / \mathrm{ml}$} & \multicolumn{4}{c|}{ NPCK, $\mu \mathrm{g} / \mathrm{ml}$} \\
\cline { 3 - 10 } & & 0.01 & 0.1 & 1 & 10 & 0.01 & 0.1 & 1 & 10 \\
\hline 1 & 2 & 3 & 4 & 5 & 6 & 7 & 8 & 9 & 10 \\
\hline $\begin{array}{c}\text { Number of cells } \\
10^{6} / \mathrm{ml},(\mathrm{n}=6)\end{array}$ & $3.0 \pm 0.4$ & $4.3 \pm 0.5$ & $4.5 \pm 0.4$ & $2.8 \pm 0.22$ & $3.4 \pm 0.3$ & $4.0 \pm 0.5$ & $3.8 \pm 0.6$ & $3.5 \pm 0.42$ & $3.0 \pm 0.5$ \\
\hline $\begin{array}{c}\text { Number of dead } \\
\text { cells, \%, }(\mathrm{n}=6)\end{array}$ & $4.6 \pm 0.8$ & $5.66 \pm 0.66$ & $5.2 \pm 0.9$ & $4.8 \pm 0.3$ & $4.16 \pm 0.7$ & $5.5 \pm 0.61$ & $5.8 \pm 0.7$ & $4.1 \pm 0.7$ & $4.16 \pm 0.74$ \\
\hline
\end{tabular}

Note: * $p<0.05$ - in comparison with control cells

In the study of morphological manifestations of apoptosis in May-Grunwald-Romanovsky staining and Heochst 33342 staining, a slight increase in the number of cells with fragmentation of the nucleus was observed at the action of minimal doses of thymalin and NPCK. When increasing the dose of peptides, the level of cells with the presence of fragmentation of the nucleus was equal to the control group (Table 2).

Table 2

Morphological signs of apoptosis under the action of thymalin and NPCK

\begin{tabular}{|c|c|c|c|c|c|c|c|c|c|c|}
\hline \multirow{2}{*}{\multicolumn{2}{|c|}{ Parameter }} & \multirow{3}{*}{$\begin{array}{l}\text { Control } \\
1.0 \pm 0.5\end{array}$} & \multicolumn{4}{|c|}{ Thymalin, $\mu \mathrm{g} / \mathrm{ml}$} & \multicolumn{4}{|c|}{ NPCK, $\mu \mathrm{g} / \mathrm{ml}$} \\
\hline & & & \multirow{2}{*}{$\begin{array}{c}0.01 \\
1.8 \pm 0.6\end{array}$} & \multirow{2}{*}{$\begin{array}{l}0.1 \\
0 \pm 0.22\end{array}$} & \multirow{2}{*}{$\begin{array}{c}1 \\
1.16 \pm 0.16\end{array}$} & \multirow{2}{*}{$\begin{array}{c}10 \\
1.33 \pm 0.2\end{array}$} & \multirow{2}{*}{$\begin{array}{c}0.01 \\
1.6 \pm 0.3\end{array}$} & \multirow{2}{*}{\begin{tabular}{c|}
0.1 \\
$1.25 \pm 0.17$
\end{tabular}} & \multirow{2}{*}{$\frac{1}{1.16 \pm 0.4}$} & \multirow{2}{*}{$\begin{array}{c}10 \\
0.5 \pm 0.36\end{array}$} \\
\hline$\frac{1}{\frac{1}{0}} \frac{\lambda}{0}$ & $\begin{array}{c}\text { Fragmen- } \\
\text { tation, } \% \\
n=6\end{array}$ & & & & & & & & & \\
\hline 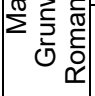 & $\begin{array}{c}\text { Conden- } \\
\text { sation, } \% \\
n=6\end{array}$ & & $4.5 \pm 0.5$ & $3.3 \pm 0.49$ & $3.0 \pm 0.57$ & $3.0 \pm 0.51$ & $4.3 \pm 0.61$ & $3.0 \pm 0.63$ & $4.0 \pm 0.44$ & $3.2 \pm 0.47$ \\
\hline 足 & $\begin{array}{c}\text { Fragmen- } \\
\text { tation, } \% \\
n=6\end{array}$ & $1.5 \pm 0.5$ & $2.3 \pm 0.7$ & $2.0 \pm 0.36$ & $1.66 \pm 0.33$ & $1.33 \pm 0.33$ & $2.5 \pm 0.42$ & $1.0 \pm 0.34$ & $1.45 \pm 0.18$ & $1.58 \pm 0.18$ \\
\hline $\begin{array}{l}0 \\
\text { co } \\
\mathbb{d} \\
\text { 우 }\end{array}$ & $\begin{array}{c}\text { Conden- } \\
\text { sation, } \% \\
n=6\end{array}$ & $4.5 \pm 0.7$ & $5.7 \pm 0.6$ & $4.66 \pm 0.33$ & $5.16 \pm 0.54$ & $4.3 \pm 0.55$ & $5.66 \pm 0.76$ & $4.5 \pm 0.42$ & $5.0 \pm 0.25$ & $5.16 \pm 0.6$ \\
\hline
\end{tabular}

Note: * $p<0.05-$ in comparison with control cells

Similar changes were observed when chromatin condensation was detected. The results of researches of electrophoretic DNA samples of cells under the action of thymalin and NPCK showed that no significant changes occurred, and no internucleosomal DNA degradation was observed (Fig. 1).

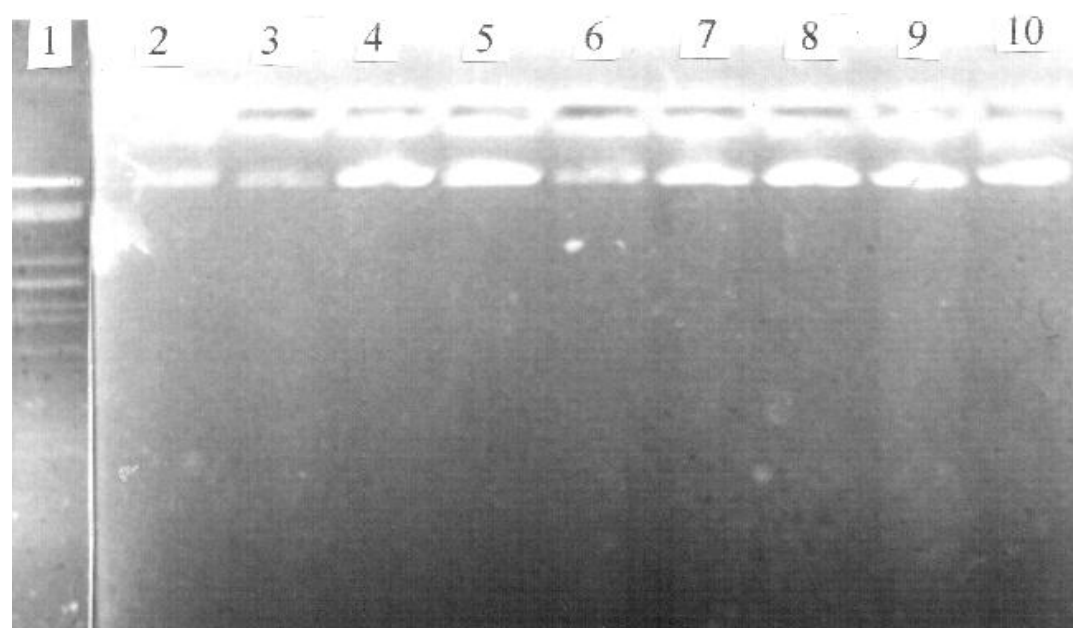

Figure 1. Analysis of internucleosomal degradation of DNA of cells of the human BJAB line at various doses of thymalin and NPCK in electrophoresis in agarose gel.

1- marker of the molecular weight of DNA of lambda phage; 2- human DNA BJAB cells (control); 3- cells that were exposed to thymalin $(0.01 \mu \mathrm{g} / \mathrm{ml}) ; 4$ - cells that were exposed to thymalin $(0.1 \mu \mathrm{g} / \mathrm{ml})$;

5- cells that were subjected to thymalin $(1 \mu \mathrm{g} / \mathrm{ml}) ; 6$ - cells that were exposed to thymalin $(10 \mu \mathrm{g} / \mathrm{ml})$;

7- cells that were exposed to NPCK $(0.01 \mu \mathrm{g} / \mathrm{ml}) ; 8$ - cells that were exposed to NPCK $(0.1 \mu \mathrm{g} / \mathrm{ml})$;

9- cells that were exposed to NPCK $(1 \mu \mathrm{g} / \mathrm{ml}) ; 10$ - cells that were exposed to NPCK $(10 \mu \mathrm{g} / \mathrm{ml})$. 
Thus, the natural peptide complexes of the thymus and kidneys have little stimulating effect on the apoptosis of tumor B-cells of the BJAB line at low concentrations, and when the dose of peptides increases, they do not affect the processes of apoptosis. It is known that separate lines of B-cells have a high level of expression of $\mathrm{Bcl}-2$, which results in their high resistance to apoptoticinducing factors [17].

Studies of the total number of HBP-ALL cells and their viability showed that the number of cells with the action of a minimum dose $(0.01 \mathrm{~kg} / \mathrm{ml})$ of thymalin and NPCK increased (Fig. 2) at doses of $0.1 \mu \mathrm{g} / \mathrm{ml}$ and $1 \mu \mathrm{g} / \mathrm{ml}$ was also higher in comparison with control cells, which was $3.5 \pm 0.24 \times 106 / \mathrm{ml}(p<0.05)$, but there was a tendency to decrease in the number of cells in comparison with the minimum dose.

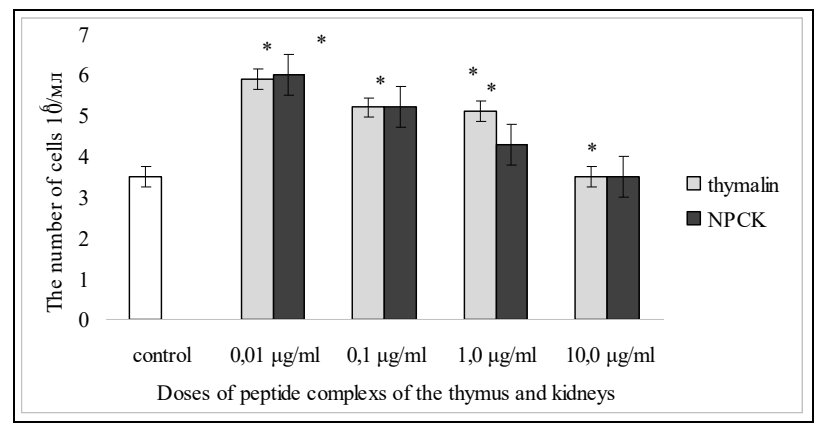

Figure 2. The total number of HBP-LLA cells under the action of natural peptide complexes of the thymus (thymalin) and kidneys (NPCK).

${ }^{*} p<0.05-$ in comparison with control cells.

At the maximum dose of peptides $(10 \mu \mathrm{g} / \mathrm{ml})$, the total number of cells was equal to the control group. Percentage of dead cells is believed to be elevated at the action of thymalin and NPCK at doses of $0.01 \mu \mathrm{g} / \mathrm{ml}, 0.1 \mu \mathrm{g} / \mathrm{ml}$, compared with control cells, where it was $5.8 \pm 0.7$ $(p<0.05)$. Along with this increase in the dose of peptides, the percentage of dead cells tended to decrease (Fig. 3).

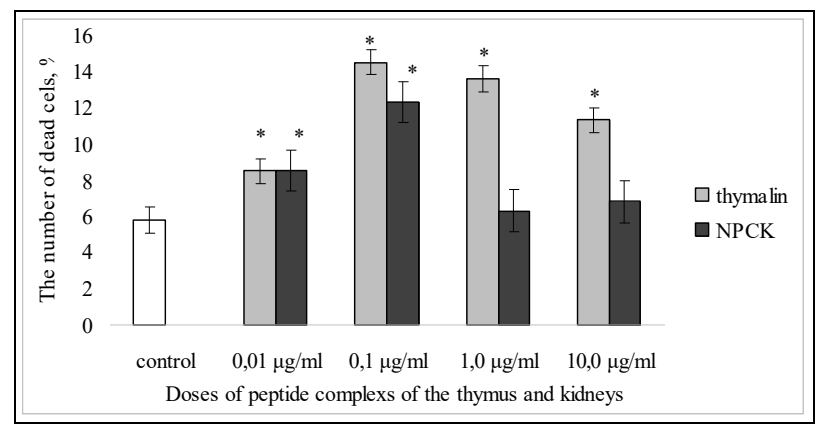

Figure 3. Viability of HBP-LLA cells under the action of natural peptide complexes of the thymus (thymalin) and kidneys (NPCK).

${ }^{*} p<0.05$ - in comparison with control cells.

In the study of morphological manifestations of apoptosis in May-Grunwald-Romanovsky staining under the influence of the examined peptide complexes, typical apoptotic signs were observed with the fragmentation and pyknosis of the nuclei, and the decrease in the volume and size of the cytoplasm. The Heochst 33342 staining, after treatment with thymalin and NPCK, revealed fluorescence clusters characteristic for nuclear DNA - fragmentation and condensation of chromatin in cells. In the control cells, the percentage of cells fragmentation and condensation in May-GrunwaldRomanovsky and Heochst 33342 staining was $1.2 \pm 0.2$ and $1.6 \pm 0.33$, respectively. A probable increase in the percentage of cells with the presence of fragmentation of the nucleus was revealed, and with effect of thymalin, this effect had a dose-dependent nature $(p<0.05)$ (Fig. 4 a, b).
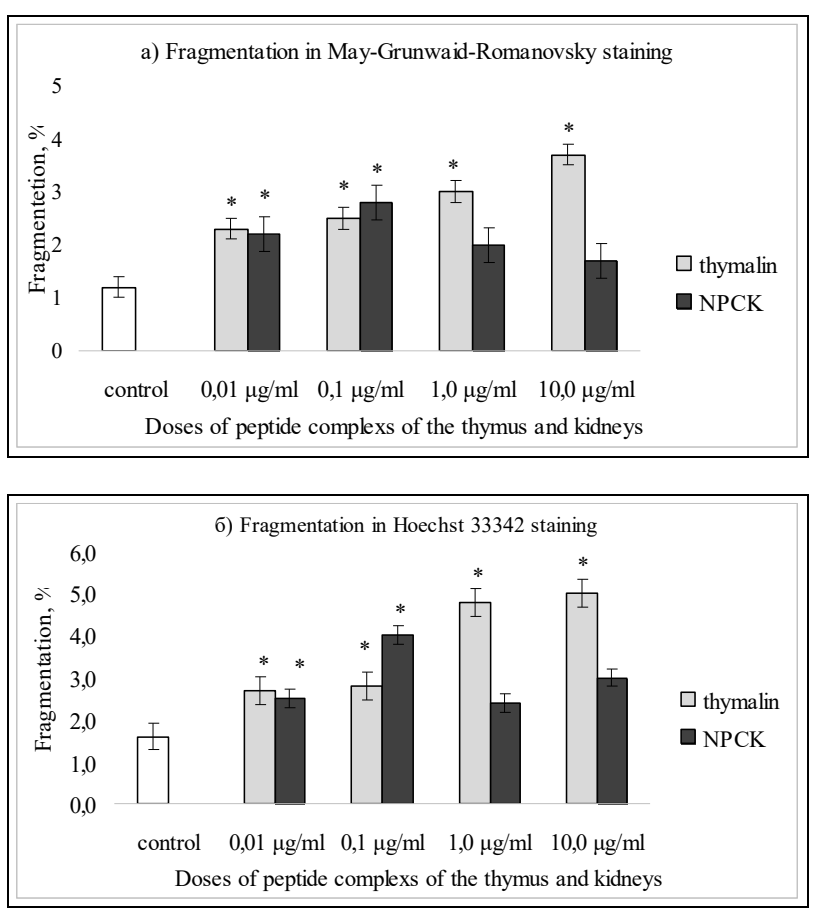

Figure 4 a,b. Morphological signs of apoptosis in May-Grunwald-Romanovsky staining under the action of natural peptide complexes of the thymus (thymalin) and kidneys (NPCK).

${ }^{*} p<0.05-$ in comparison with control cells.

Similar changes were observed when chromatin condensation was detected, but this effect was more pronounced in the action of thymalin than in the NPCK. In the control cells, chromatin condensation was detected in May-Grunwald-Romanovsky and Heochst 33342 staining at $3.5 \pm 0.34$ and $4.0 \pm 1.0$ percent of cells, respectively. An increase in the dose of thymalin resulted in an increase in the number of cells subjected to apoptosis. At the action of NPCK, we observed a multi-directional phase effect: the small doses of peptide stimulated apoptosis, whereas the large ones suppressed it (Fig. 5 a, b). The effect of peptides in small doses is due to the generalization of the signal by the formation of secondary messengers, and with the increase in dose, hyperactivation of systems is observed, which can lead to the suppression of the effect [18].

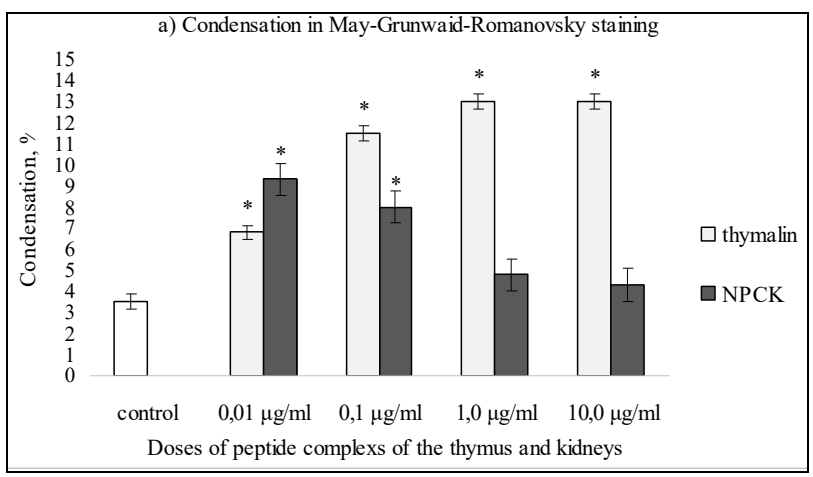




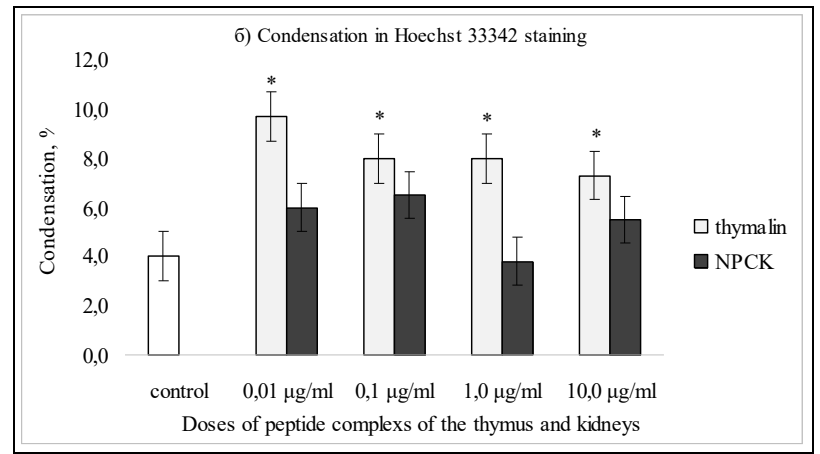

Figure 5 a,b. Morphological signs of apoptosis in Hoechst 33345 staining under the action of natural peptide complexes of the thymus (thymalin) and kidneys (NPCK). ${ }^{*} p<0.05-$ in comparison with control cells.
The results of studies of electrophoretic DNA samples of cells under the action of thymalin and NPCK showed that no significant changes occurred, internucleosomal degradation of DNA was not observed (Fig. 6).

Thus, the natural peptide complexes of the thymus and the kidneys are capable of reinforcing the processes of apoptosis in the transformed T-cells. With the action of natural peptide complex of thymus, this effect has a dose-dependent character.

Consequently, the natural peptide complexes of thymus and kidneys are likely to increase the processes of elimination of the transformed T-cells by activating apoptosis processes in them, but they do not affect the processes of apoptosis of the transformed B-cells. One of the mechanisms of action of peptides may be their ability to bind to the molecules of MHC-I class, which can participate in the implementation of their actions [19].

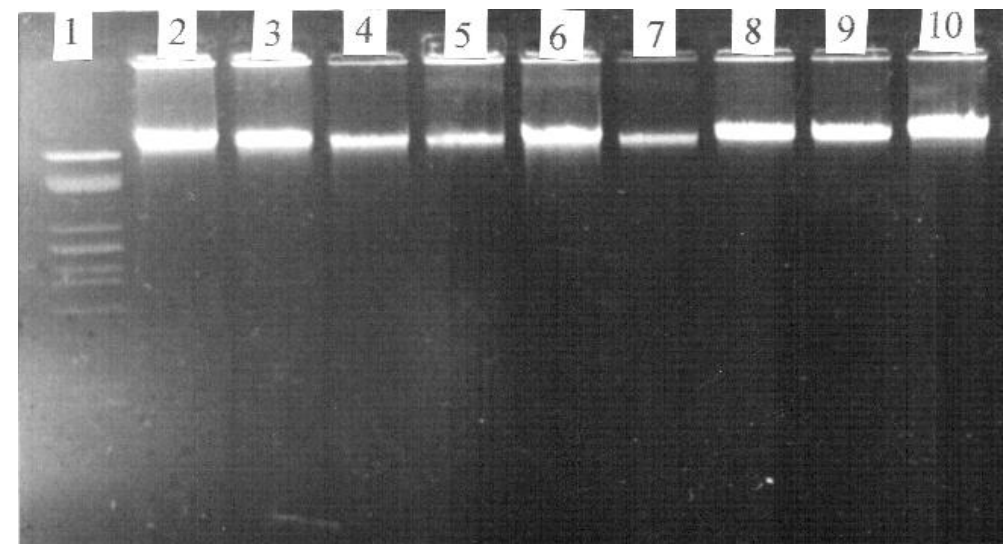

Fig.6. Analysis of internucleosomal degradation of DNA cells of the HPB-ALL

line under various doses of thymalin and NPCK in agarose gel electrophoresis

1- marker of molecular weight: DNA of lambda-phage is cut with restrictase pst

1: 2- human DNA cells of the HPB-ALL line (control); 3- cells that were exposed to thymalin $(0.01 \mu \mathrm{g} / \mathrm{ml})$;

- cells subjected to the action of thymalin $(0.1 \mu \mathrm{g} / \mathrm{ml}) ; 5$ - cells subjected to the action of thymalin $(1 \mu \mathrm{g} / \mathrm{ml})$

6- cells that were exposed to thymalin $(10 \mu \mathrm{g} / \mathrm{ml}) ; 7$ - cells that were exposed to NPCK $(0.01 \mu \mathrm{g} / \mathrm{ml})$;

8- cells that were exposed to thymalin of NPCK $(0.1 \mu \mathrm{g} / \mathrm{ml}) ; 9$ - cells that were exposed to NPCK $(1 \mu \mathrm{g} / \mathrm{ml})$; 10 - cells that were exposed to NPCK $(10 \mu \mathrm{g} / \mathrm{ml})$.

The obtained data confirm the conclusion that peptide bioregulators exhibit the greatest activity in relation to the tropical type of cells and tissues. Presumably, there are specific sites on the cell surface that perceive the effect of thymic peptides on the apoptosis program in a differentiated manner [20]. One of the mechanisms of action of peptides may be their ability to bind to the molecules of MHC-I class, which can participate in the implementation of their actions.

\section{References}

1. VDAC2 enables BAX to mediate apoptosis and limit tumor development / H.S. Chin, M.X. Li, I.K.L. Tan [et al.] // Nat. Commun. - 2018. - Vol. 9 (1). - P. 4976.

2. Kaser H.E. The role of apoptosis in normal ontogenesis and solid human neoplasms / H.E. Kaser, B. Bodey // In. Viv. - 2000. - Vol. 14, N. 6. - P. 789-803.

3. Reed J.C. Apoptosis-based therapies for hematologic malignancies / J.C. Reed, M. Pellecchia // Blood. - 2005. - Vol. 106. - P. 408-418.

4. Cheredeev A.N. Apoptoz kak vazhnyy etap ozenki immunnoy sistemy po patogeneticheskomu prinzipu / A.N. Cheredeev, L.V. Koval'chuk // Klinicheskaya laboratornaya diagnostika. - 1997. - № 7. - S. 31-34.

5. Johnstone R.W. Apoptosis: A Link between Cancer Genetics and Chemotherapy / R.W. Johnstone, A. A. Ruefli, S.W. Lowe // Cell. - 2002. - Vol. 108. - P. 153-164.

6. PIM1 overexpression in T-cell lymphomas protects tumor cells from apoptosis and confers doxorubicin resistance by upregulating c-myc expression / X. Xiang, Di Yuan, Yao Liu [et al.] // Acta Biochim. Biophys. Sin. - 2018. - P. 1-7.

7. Methotrexate induces high level of apoptosis in canine lymphoma/leukemia cell lines / A. Pawlak, J. Kutkowska, B. Obminska-Mrukowicz [et al.] // Res. Vet. Sci. - 2017. Vol. 114. - P. 518-523.

8. ONC201 selectively induces apoptosis in cutaneous T-cell lymphoma cells via activating pro-apoptotic integrated stress response and inactivating JAK/STAT and NFkappaB pathways / X. Ni, X. Zhang, C.H. Hu [et al.] // Oncotarget. - 2017. - Vol. 8. - P. 61761-61776.

9. Tripeptid neogen usilivaet apoptoz T-limfozitov cheloveka pri ich otvete na mitogen / M.F. Nikonova, T.Yu. Grigor'eva, M.M. Litvina [i dr.] // Immunologiya. - 2000. № 4. - S. 35-37.

10. Dracorhodin perchlorate induces apoptosis in primary fibroblasts from human skin hypertrophic scars via participation of caspase 3 / P. Zhang, J. Li, X. Tang [et al.] // Eur. J. Pharmacol. - 2014. - Vol. 728. - P. 82-92.

11. Anti-cancer activity of targeted pro-apoptotic peptides / H.M. Ellerby, W. Arap, L.M. Ellerby [et al.] // Nat. Med. 1999. - Vol. 5, N. 9. - P. 1032-1038.

12. Zinchenko S.V. Immunomodulyatory $v$ kompleksnoy terapii onkologicheskich bol'nych (obzor literatury) / S.V. Zinchenko // Povolzhskiy onkologicheskiy vestnik. - 2014. - № 1. - S. 57-64.

13. Patent 10180 Ukraïna, MPK A61 K37/00. Sposib oderzhannya biologichno aktivnoï rechovini, scho maє regeneratornu ta modulyuyuchu diyu / Kaydashev I.P., Katrushov O.V.; zayavnik i patentovlasnik TOV «Farmapol». - № 94052069 ; zayavl. 30.05.1994 ; opubl. 15.05.2001, Byul. 4. 


\section{Tom 22, N 3-4 2018 p.}

14. Metodi klinichnich ta eksperimental'nich doslidzhen' v medizini / [L.V. Berkalo, O.V. Bobovich, N.O. Bobrova ta in.]; pid red. I.P. Kaydasheva - Poltava: Polimet, 2003. $320 \mathrm{~s}$.

15. Osobennosti indukzii apoptoza etopozidom $v$ razlich-nych zlokachestvennych limfoidnych kletochnych liniyach cheloveka / Z.A. Butenko, M.P. Zavelevich, I.A. Smirno-va [i dr.] // Eksperimental'naya onkologiya. - 2000. - T. 22, № 1-2. - S. 26-31.

16. Traganos F. Lysosomal proton pump activity: Supravital cell staining with acridine orange differential leukocytes subpopulations / F. Traganos, Z. Darzynkiewicz // Meth. Cell Biol. - 1994. - N. 41. - P. 185-195.

17. Protein Tyrosine Kinases p53/56 $6^{\text {lyn }}$ i p $72^{\text {syk }}$ in $\mathrm{MHC}$ class I-Mediated signal Transduction in B-Lymphoma Cells / A.E. Pedersen, S. Bregenholt, S. Skov [et al.] //
Experimental Cell Research - 1998 - Vol. 240 - P 144150.

18. Kuznik B.I. Imunofan - sinteticheskiy peptidnyy preparat novogo pokoleniya: immunologicheskie i patogeneticheskie aspekty klinicheskogo primeneniya / B.I. Kuznik, V.V. Lebedev // Immunologiya. - 1999. - № 1. S. 25-30.

19. Kaydashev I.P. Rol' molekul MNS I klassa na opucholevych T-kletkach $v$ peredache peptidnogo signala / I.P Kaydashev, O.A. Nozhinova // Imunologiya ta alergologiya. - 2002. - № 2. - S. 22-25.

20. Samara P. Prothymosin Alpha and Immune Responses: Are We Close to Potential Clinical Applications? / P. Samara, K. Ioannou, O.E. Tsitsilonis // Vitam. Horm. 2016. - Vol. 102. - P. 179-207.

Матеріал надійшов до редакції 03.10.2018 